\title{
Thoracale autopercussie
}

In de vorige nummers van het TMO heeft $\mathrm{u}$ kunnen lezen dat ons tijdschrift een grote stap gaat maken naar Engelstaligheid met de titel: Perspectives on Medical Education (PME). De redactie is druk bezig deze overgang voor te bereiden. We zijn niet over één nacht ijs gegaan; het was een goed overwogen beslissing die we durfden te nemen omdat er al een stevige basis is in Nederland en Vlaanderen. Wij zijn op het gebied van onderzoek van medisch onderwijs internationaal gerenommeerd, maar wij zijn echter niet zo goed in thoracale autopercussie. In een Redactioneel mag het echter wel eens worden gezegd dat de rest van de wereld naar ons (op)kijkt. Wij zijn een gidsland met de verantwoordelijkheid die daarbij hoort. Dat is mede de reden geweest om het besluit te nemen 'internationaal te gaan'. Als we binnen enkele jaren de status van belangrijk internationaal forum voor onderzoek van medisch onderwijs(vernieuwingen) hebben bereikt, zijn wij als redactie tevreden. Hierbij realiseren we ons dat we dat mede te danken hebben aan de vruchtbare Nederlandse en Vlaamse bodem die er nu al is en aan de grote stroom van relevant onderzoek die hier al bestaat. Een stroom die ook 'ons tijdschrift' zal gaan 'irrigeren' en tot bloei zal laten komen. We hopen dan ook dat vele auteurs hun manuscripten naar het nieuwe tijdschrift zullen gaan sturen, ook al kunnen we nog niet bogen op een impactfactor. Het aantal promovendi op ons vakgebied neemt toe; deze promovendi hebben dikwijls onderzoeksonderdelen die slechts een hoofdstuk in de dissertatie worden en verder niet gepubliceerd worden, maar wel voor een breder - internationaal - publiek interes- sant zijn en dus toegankelijk zouden moeten zijn. Het ligt voor de hand deze vaak kwalitatief goede onderzoeksrapportages, en uiteraard ook andere artikelen die soms elders (net) niet gepubliceerd kunnen worden, de komende tijd in PME een kans te geven.

In het nu voor $\mathrm{u}$ liggende nummer van het TMO is weer een aantal interessante bijdragen te lezen. Aper et al. rapporteren over een fraai onderzoek naar het verschil in volledig docentgeleide en deels zelfstandige consulttrainingen. De uitkomst is opmerkelijk.

Voorts een overzicht door Schreuder et al. over drie vakgebieden die gebruik maken van Minimale Invasieve Chirurgie, waarin zij de - lastige - implementatie van simulatietrainingen beschrijven. Dit artikel is een dubbelpublicatie met Medical Teacher en daarom in het Engels (een voorproefje).

Coassistenten krijgen weinig feedback, té weinig zeggen Van Hirtum et al. In hun onderzoek hebben zij coassistenten, supervisoren en onderwijskundigen bevraagd over de hoeveelheid en kwaliteit van feedback, maar ook over hoe het komt dat het zo moeilijk is feedback te geven of te vragen. De uitkomsten leiden tot heldere aanbevelingen.

Gerards-Last en Geraets gunnen ons een kijkje in het brein van fysiotherapeuten die het klinisch redeneren wordt geleerd. De nieuwe aanpak, competentiegericht, lijkt vruchten af te werpen. De voortzetting van dit onderzoek zal meer duidelijkheid moeten geven over waarom dit zo (b)lijkt te zijn. 
Van Weel-Baumgarten et al. voeren ons in in de wereld van simulatiepatiënten en gestandaardiseerde patiënten en doen mede vanuit hun eigen ervaring suggesties over de manier waarop deze beide groepen kunnen worden geselecteerd, getraind en ingezet.

Een 'anders-dan-anders' bijdrage is het verslag over de Medische Publieksacademie, die in het UMC Groningen zeer veel belangstellenden trekt. Het publiek wordt voorgelicht over bepaalde ziektebeelden, en deze 'state of the art' informatie wordt veelal interactief gebracht. Een mooi initiatief in deze tijd waarin veel informatie voor patiënten niet onafhankelijk en niet objectief (b)lijkt te zijn.

Weer veel leesplezier gewenst!

\section{Peter Boendermaker}

